\title{
Different Characteristics of Neuroblastomas in Cases Found by Mass Screening and Non-screening: Evaluation of Mass Screening for Neuroblastoma in Kitakyushu City
}

\author{
Nobuaki ARIYOSHI \\ Department of Pediatrics, School of Medicine, University of Occupational and Environmental \\ Health, Japan. Yahatanishi-ku, Kitakyushu 807, Japan
}

Abstract: Neuroblastoma accounts for 24 of 109 patients who have been managed by the pediatric tumor outpatient clinic of our university hospital. Among the malignant solid tumors, neuroblastomas are the most numerous. We investigated neuroblastomas found by mass screening oncologically and epidemiologically. Up until March 31, 1991, seven cases were detected from 64,885 infants who received mass screening by the Kitakyushu City System which we had introduced in 1985. This system is based on an individual health survey program for infants in the city. Six of seven cases found by the screening were treated in our department. None of them, including stage III and stage IV cases, showed any conventional risk factors such as high serum levels of neuron specific enolase, ferritin, amplification of N-myc gene, nor cytogenetic abnormalities. Histopathological studies revealed that ganglioneuroblastoma was observed in 9 of 13 cases over one year of age, whereas it was observed only in two screened cases out of 11 cases under one year of age. According to the classification of Shimada et al., there was one stroma-rich tumor, which is rare in infants and usually a matured type, in the screened cases. Interestingly, another one of the six screened cases regressed spontaneously without any treatment. These cases suggested that some neuroblastomas in the process of maturation or spontaneous regression could be detected by mass screening. On the other hand, 9 of 13 non-screened cases over one-year-old died. Although mass screening at six months of age decreased the mortality rate by neuroblastoma in infancy, the prognosis of neuroblastoma in patients over one-year-old remained still poor. Mass screening should be carried out in a health survey program at one year and six months of age in order to improve the outcome.

Key words: neuroblastoma, mass screening, prognostic risk factors, spontaneous regression.

(Received 29 January 1993, accepted 10 August 1993)

\section{Introduction}

Mass screening (MS) by a qualitative determination of VMA (vanillylmandelic acid) excreted into the urine from neuroblastoma cells has been conducted in the Kyoto district since 1973 [1]. Sawada et al. reported that MS was able to improve the prognosis of neuroblastoma in infancy [2]. In Kitakyushu City, MS by a quantitative analysis of both urinary VMA and HVA (homovanillic acid) has been performed since April, 1985. We 
introduced MS in cooperation with the medical association of the city [3]. During the past six years, we have given medical treatment to six of seven cases found by MS in the Kitakyushu City System. The MS receiving rate exceeded $90 \%$, which is about $20 \%$ higher than the mean for the whole country. The frequency of detection by MS was 1/8396, about 1.5 times the mean for the whole country [4].

After the introduction of MS into the national scale in 1985, the annual number of patients with neuroblastoma in infancy tripled compared to the number of those before the introduction of MS [5-8]. Furthermore, because only 8 of 441 patients found by MS died throughout 1988, the outcome appears to have become better [4]. However, some recent reports showed that there were late-presenting neuroblastomas which had not been detected by MS [9-11]. Therefore, it is suggested that even if neuroblastoma in infancy is found early by MS, the screening may not provide much of a remedy for unfavorable patients with neuroblastoma over one year of age. In order to evaluate the results of MS in Kitakyushu City, the difference between the oncological findings and the clinical prognosis of the mass screened cases under one-year-old and the non-screened cases over one-year-old were studied. We found that neuroblastoma in infancy had a good prognosis even if the clinical stage was advanced.

\section{Patients and Methods}

Patients: Six male and five female cases aged under one year, who were diagnosed in our department from 1981 to 1991, were divided into two groups; the first consisting of the cases found by MS (group A) and the second consisting of non-screened cases (group B). A third group, non-screened, consisted of cases with neuroblastoma who were over one-yearold and who were being treated in our hospital or at another hospital (group G). Their primary involved organs and clinical stages were determined at the time of the initial operation or biopsy in all cases except patient 9, for whom all treatment, including surgery, was rejected. The most common primary organs involved in the cases aged under one year were the adrenal glands. In particular, the adrenal glands were the primary organs involved in all cases in group B. The clinical stage of all cases was determined according to Evans' classification [12].

Kitakyushu City System of MS for neuroblastoma: The system is based on an individual health survey program. The health survey for children is not an individual but a group checkup in most regions of Japan other than Kitakyushu City. In our system, four-month-old, seven-month-old, one-year-six-month-old and three-year-old infants visit a pediatrician at a private office or hospital in the city. The health survey receiving rate is higher in Kitakyushu City than in other regions [13]. When four-month-old infants are physically examined in Kitakyushu City, the MS system for neuroblastoma is explained to the mothers and they are given a urine collecting filter paper. Each mother should mail a 
urine sample on filter paper when her infant is six months of age.

Laboratory studies: Urinary levels of VMA and HVA were determined by highperformance liquid chromatography [14]. Serum levels of neuron-specific enolase (NSE) and ferritin were determined by radioimmunoassay $[15,16]$. An analysis of the N-myc gene by southern blotting and the chromosome analysis using the G-band technique was also performed in some cases $[17,18]$.

Pathological studies: All specimens, except three, were obtained before treatment. The tumor specimen from patient 20 was obtained at autopsy, and those from patient 23 and 24 were obtained at the time of recurrence after off-therapy. The histopathological classification was based on the Histological Classification of Childhood Tumors of the Japanese Pathological Society [19] . A ganglioneuroblastoma was subclassified as welldifferentiated (2a), composite (2b) and poorly differentiated (2c) types, and neuroblastoma as rosette-fibrillary (3a) and round cell (3b) types. Hematoxylin-eosin (H-E) stained specimens were classified as stroma-poor and stroma-rich types according to the classification of Shimada et al., and the tumors of the stroma-poor type were separated into undifferentiated and differentiating histologies [20]. After the mitosis-karyorrhexis index (MKI) was calculated, we determined whether the tumors were higher-MKI tumors (patients aged under one year six months, 200 or more per 5000 cells; patients aged over one year six months, 100 or more per 5000 cells). Tumors of the stroma-rich type were divided into well-differentiated, intermixed and nodular types. S-100 protein staining was performed as an immunohistological staining. The septum separating tumor cells in the stroma-poor type was examined, and S-100 protein-positive and negative groups were determined [21].

Statistical analyses: Survival curves were plotted by the Kaplan-Meier method and a significant difference was determined by the generalized Wilcoxon test. Associations between pairs of categorical variables were assessed with chi-square statistic.

\section{Results}

Clinical aspects of neuroblastomas under one year of age: Two of six screened cases were in the advanced clinical stages, however, the other cases under one-year-old were in the early stages (Table 1). All cases except patient 5 had elevated levels of urinary excretion of both VMA and HVA. The VMA/HVA ratio was lower than 1.0 in six cases. With regard to conventional risk factors, the serum NSE and ferritin levels were not abnormally high in any of the cases, and in the four cases whose N-myc genes could be analyzed, there was no amplification. Including the two advanced cases, all 11 cases under one-year-old are alive, whereas 9 of 13 non-screened cases of over one-year-old have 
Table 1. Clinical and laboratory data of neuroblastoma patients under one year of age

\begin{tabular}{|c|c|c|c|c|c|c|c|c|c|c|c|c|}
\hline No & Name & Sex & Age & Group & $\begin{array}{c}\text { Primary }^{* 2} \\
\text { organ }\end{array}$ & Stage & $\begin{array}{c}\text { VMA } \\
(\mu g / \mathrm{mgcre})\end{array}$ & $\begin{array}{c}\text { HVA } \\
(\mu g / \text { mgcre })\end{array}$ & $\begin{array}{c}\mathrm{NSE} \\
(\mathrm{ng} / \mathrm{ml})\end{array}$ & $\begin{array}{l}\text { Ferritin } \\
(\mathrm{ng} / \mathrm{ml})\end{array}$ & $\begin{array}{c}\mathrm{N} \text {-myc } \\
\text { amplification }\end{array}$ & Chromosome \\
\hline 1 & $\mathrm{SN}$ & M & $0 \mathrm{~m}$ & $\mathrm{~B}$ & $\mathrm{Ad}$ & IV-S & 76.2 & 177.9 & 20.0 & 288.9 & nd & nd \\
\hline 2 & MM & $\mathrm{F}$ & $1 \mathrm{~m}$ & $\mathrm{~B}$ & $\mathrm{Ad}$ & IV $-\mathrm{S}$ & 241.9 & 202.8 & 11.6 & 270.6 & $(-)$ & nd \\
\hline 3 & MI & $\mathrm{F}$ & $1 \mathrm{~m}$ & B & $\mathrm{Ad}$ & $\mathrm{IV}-\mathrm{S}$ & 34.9 & 65.2 & 12.0 & 170.0 & nd & nd \\
\hline 4 & EK & $\mathrm{F}$ & $1 \mathrm{~m}$ & B & $\mathrm{Ad}$ & I & 25.8 & 15.2 & 14.0 & 147.0 & nd & nd \\
\hline 5 & $\mathrm{TH}$ & $\mathrm{M}$ & $3 \mathrm{~m}$ & $\mathrm{~B}$ & Ad & IV-S & 18.1 & 2.2 & nd & 46.7 & nd & nd \\
\hline 6 & $\mathrm{MH}$ & $\mathrm{F}$ & $7 \mathrm{~m}$ & $\mathrm{~A}$ & Ret & IV & 111.9 & 115.6 & 30.0 & 82.8 & $(-)$ & triploid \\
\hline 7 & $\mathrm{SM}$ & $\mathrm{F}$ & $7 \mathrm{~m}$ & $\mathrm{~A}$ & $\mathrm{Ad}$ & I & 39.5 & 27.1 & 8.7 & 18.6 & $(-)$ & nd \\
\hline 8 & $\mathrm{TM}$ & M & $7 \mathrm{~m}$ & $\mathrm{~A}$ & Med & III & 109.3 & 41.9 & 47.0 & 80.6 & nd & nd \\
\hline 9 & JN & M & $7 \mathrm{~m}$ & $\mathrm{~A}$ & $\mathrm{Ad}$ & IV $-\mathrm{S}$ & 17.7 & 46.3 & 7.8 & nd & nd & nd \\
\hline 10 & SK & M & $8 \mathrm{~m}$ & $\mathrm{~A}$ & $\mathrm{Ad}$ & I & 30.8 & 45.4 & 9.1 & 24.5 & nd & nd \\
\hline 11 & $\mathrm{SA}$ & $\mathrm{M}$ & $8 \mathrm{~m}$ & $\mathrm{~A}$ & $\mathrm{Ad}$ & I & 27.7 & 38.0 & 16.0 & 23.0 & $(-)$ & hypertetraploid \\
\hline \multicolumn{11}{|c|}{$\begin{array}{l}{ }^{* 1} \text { Group } A ; \text { screened cases } \\
\text { Group } \mathrm{B} ; \text { non-screened cases }\end{array}$} & \multicolumn{2}{|c|}{$\begin{array}{l}{ }^{* 2} \text { Ad ; adrenal gland } \\
\text { Ret ; retroperitoneum } \\
\text { Med ; mediastinum }\end{array}$} \\
\hline
\end{tabular}

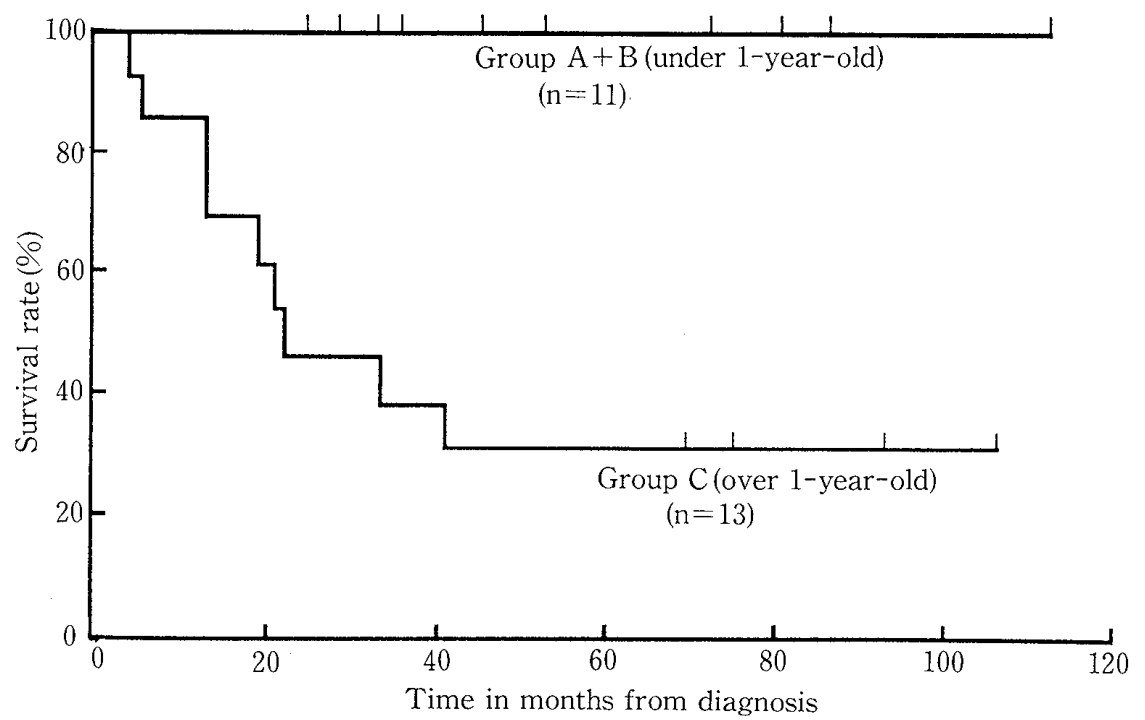

Fig. 1 Kaplan-Meier analysis of survival times for 11 cases in group A + B (under 1-year-old) and 13 cases in group $\mathrm{C}$ (over 1-year-old). The difference in survival times between group $\mathrm{A}+$ $\mathrm{B}$ and group $\mathrm{C}$ was significant $(P<0.005)$.

died. The difference between survival rates is significant at the $P<0.005$ level (Fig. 1).

The clinical courses of the three unique cases found by MS are reported briefly. Patient 6 and 8 were in stage III and stage IV, respectively. Interestingly, patient 9 regressed spontaneously without any treatment. 
Patient 6: In April, 1990, a girl was screened at the age of six months, and the values of VMA and HVA were 111.9 and $115.6 \mu \mathrm{g} / \mathrm{mg}$ cre, respectively. After she was referred to our hospital, an abdominal mass and skin nodules were seen. Bone marrow aspiration was negative, and a bone radio survey showed no metastatic lesions. The echogram, computed tomographic (CT) scan and magnetic resonance (MR) showed a huge retroperitoneal mass. The serum NSE was $30.0 \mathrm{ng} / \mathrm{ml}$, and ferritin was $80.8 \mathrm{ng} / \mathrm{ml}$. An exploratory laparotomy confirmed the retroperitoneal tumor and histology of the biopsy showed neuroblastoma of the rosette-fibrillary type. N-myc of the primary tumor was not amplified. The tumor had modal chromosome numbers in the triploid range. The deletion of the short arm of chromosome 1 (lp) was not seen, nor was the homogeneously staining region (HSR) or double minutes (DMs) were observed. After the administration of $200 \mathrm{mg} / \mathrm{m}^{2}$ of cyclophosphamide (CPM) and $1.0 \mathrm{mg} / \mathrm{m}^{2}$ of vincristine (VCR) every week for nine weeks, the levels of VMA and HVA were decreased to 28.6 and $22.4 \mu \mathrm{g} / \mathrm{mg}$ cre, respectively, and the primary tumor had regressed and skin nodules had disappeared. Although the retroperitoneal tumor was not completely extirpated at surgery in June, 1990, the postoperative chemotherapy induced a complete remission. Up until April, 1992, she received 12 courses of the chemotherapeutic regimen that included $300 \mathrm{mg} / \mathrm{m}^{2} \times 5$ days of GPM and $35 \mathrm{mg} / \mathrm{m}^{2}$ of pirarubicin (THP-adriamycin, THP-ADM). She is now diseasefree.
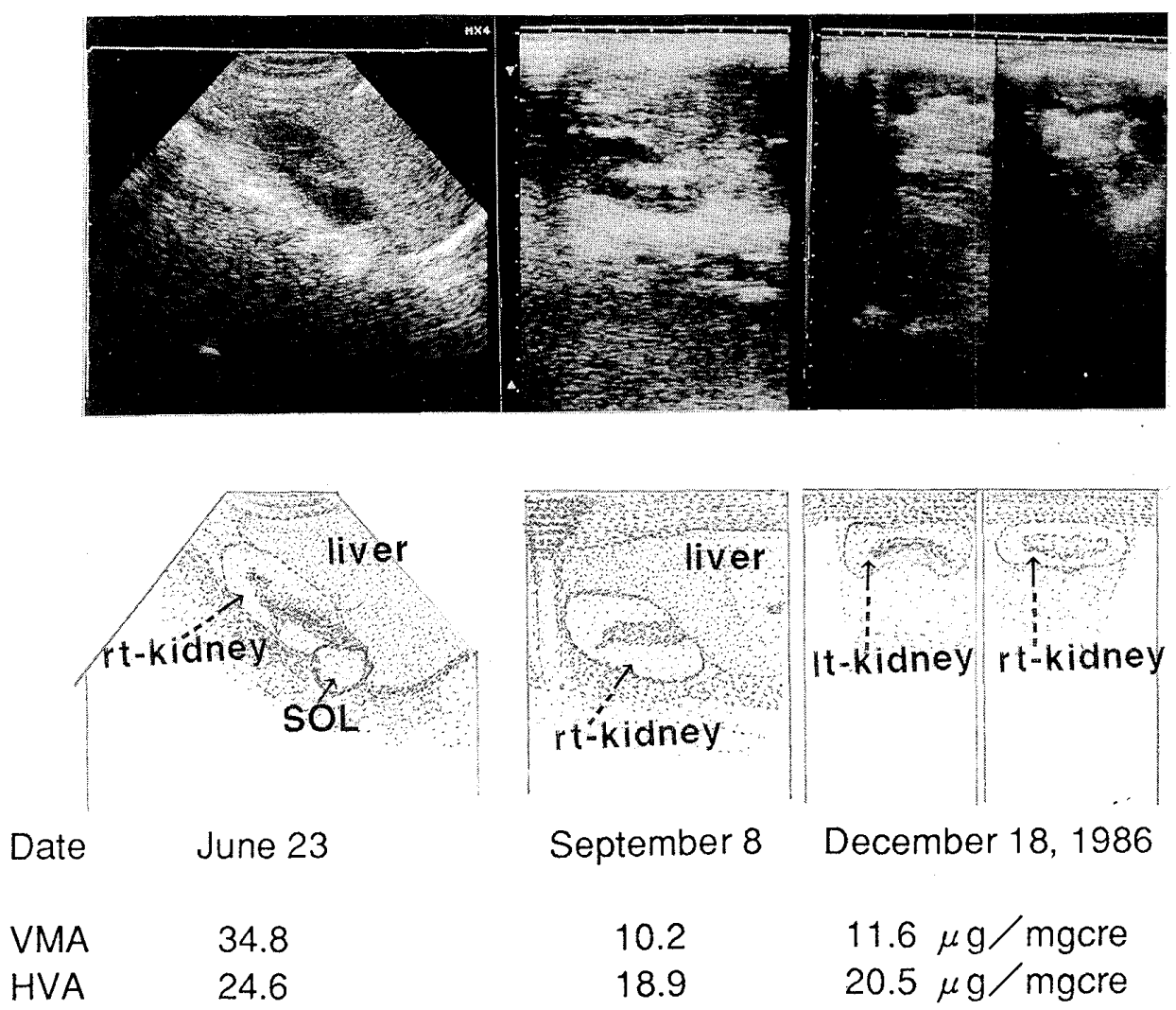

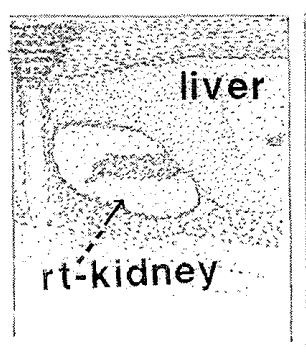

September 8

10.2

18.9

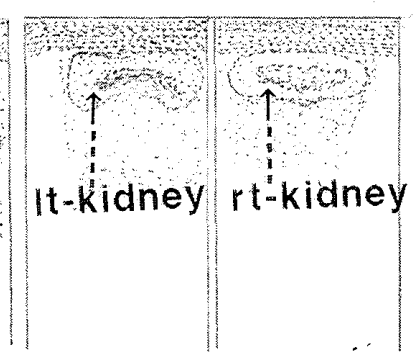

December 18, 1986

$11.6 \mu \mathrm{g} / \mathrm{mgcre}$

$20.5 \mu \mathrm{g} / \mathrm{mgcre}$

Fig. 2 Right suprarenal tumor on the echogram and urinary levels of VMA and HVA of patient 9. 
Patient 8: A boy also was screened at the age of six months, and the values of VMA and HVA were 109.3 and $41.9 \mu \mathrm{g} / \mathrm{mg}$ cre, respectively. On September 7, 1988, he was admitted to our hospital. The chest $\mathrm{x}$-ray and $\mathrm{C}$ T revealed a posterior mediastinal mass contained calcification. The seventh intercostal space was extended due to the tumor. A mediastinal mass, $6.3 \times 4.5 \times 4.0 \mathrm{~cm}$ in size $(69 \mathrm{~g})$, was completely extirpated by a thoracotomy on September 30. After surgery, 20 courses of CPM $300 \mathrm{mg} / \mathrm{m}^{2} \times 5$ days and THP-ADM $35 \mathrm{mg} / \mathrm{m}^{2}$ were administrated for two years. At the present time he is well.

Patient 9: A seven-month-old boy was referred to our hospital on May 8, 1986. On MS, urinary VMA was 38.0 and HVA was $47.2 \mu \mathrm{g} / \mathrm{mg}$ cre. A right abdominal tumor was palpable, but his parents rejected the treatment. On June 23, the echogram showed a right suprarenal tumor, but liver metastases was not revealed. Both x-ray and CT were rejected by the parents. However, we tried to persuade his parents to have the tumor extirpated but this was also rejected. When he came to the hospital again for an examination on September 8, the tumor had regressed spontaneously and urinary catecholamines were normalized without any medical treatment (Fig. 2). He is still well, however, no adequate assessment has been able to be made.

Histopathological analyses: The histopathological studies showed that ganglioneuroblastoma in group $C_{\text {. }}$ (patients aged over one year) was observed in 9 of 13 cases, while it was observed only in two screened cases aged under one year (Table 2). According to the classification of Shimada et al. [20], nine of the ten cases aged under one year had undifferentiated stroma-poor, lower-MKI tumors (Fig. 3), and the other had a

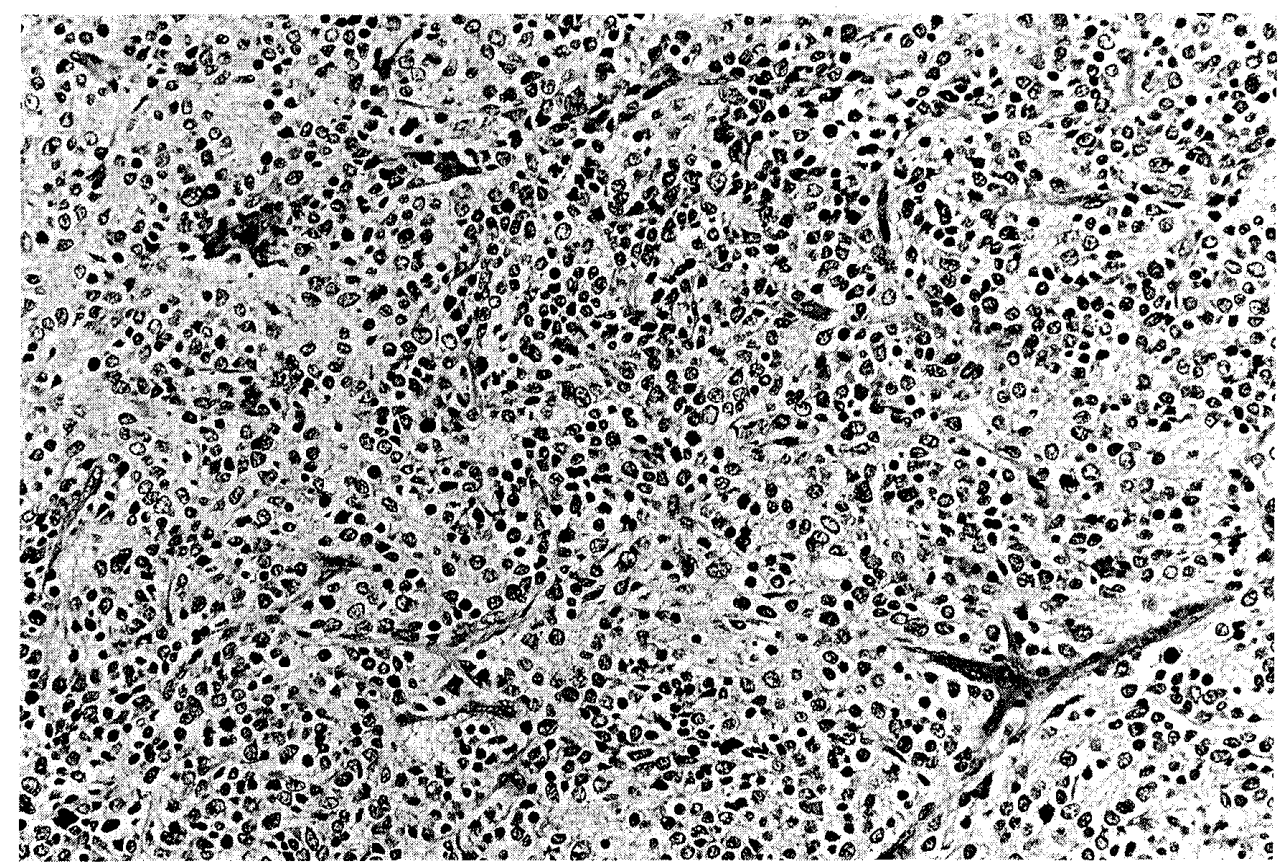

Fig. 3 Undifferentiated stroma-poor with lower-MKI neuroblastoma (patient 7) accoding to the classification of Shimada et al. [20]. Hematoxylin-eosin stain. $\quad \times 50$. 
Table 2. Histhopathological findings and outcome of 24 cases with neuroblastoma

\begin{tabular}{|c|c|c|c|c|c|c|c|c|c|}
\hline \multirow[b]{2}{*}{ No } & \multirow[b]{2}{*}{ Age } & \multirow[b]{2}{*}{ Group $^{* 1}$} & \multirow[b]{2}{*}{ Pathology ${ }^{* 2}$} & \multicolumn{3}{|c|}{ Classification of Shimada et al } & \multirow{2}{*}{$\begin{array}{c}\text { S-100 } \\
\text { protein } \\
\text { staining }\end{array}$} & \multirow{2}{*}{$\begin{array}{l}\text { Follow up } \\
\text { interval } \\
\text { (months) }\end{array}$} & \multirow[b]{2}{*}{ Outcom } \\
\hline & & & & Stroma & Differentiation *3 & MKI & & & \\
\hline 1 & $0 \mathrm{~m}$ & $\mathrm{~B}$ & $3 a$ & poor & undifferent & lower & + & 45 & alive \\
\hline 2 & $1 \mathrm{~m}$ & $\mathrm{~B}$ & $3 a$ & poor & undifferent & lower & + & 87 & alive \\
\hline 3 & $1 \mathrm{~m}$ & $\mathrm{~B}$ & $3 a$ & poor & undifferent & lower & nd & 73 & alive \\
\hline 4 & $1 \mathrm{~m}$ & $\mathrm{~B}$ & $3 a$ & poor & undifferent & lower & + & 28 & alive \\
\hline 5 & $3 \mathrm{~m}$ & $\mathrm{~B}$ & $3 a$ & poor & undifferent & lower & nd & 113 & alive \\
\hline 6 & $7 \mathrm{~m}$ & $\mathrm{~A}$ & $3 a$ & poor & undifferent & lower & $2+$ & 34 & alive \\
\hline 7 & $7 \mathrm{~m}$ & $\mathrm{~A}$ & $3 a$ & poor & undifferent & lower & + & 25 & alive \\
\hline 8 & $7 \mathrm{~m}$ & $\mathrm{~A}$ & $3 a$ & poor & undifferent & lower & + & 53 & alive \\
\hline 9 & $7 \mathrm{~m}$ & $\mathrm{~A}$ & nd & nd & nd & nd & nd & 81 & alive \\
\hline 10 & $8 m$ & A & $2 b$ & poor & undifferent & lower & + & 87 & alive \\
\hline 11 & $8 \mathrm{~m}$ & $\mathrm{~A}$ & $2 c$ & rich & intermixed & nd & nd & 36 & alive \\
\hline 12 & 1y & $\mathrm{C}$ & $2 \mathrm{c}$ & poor & different & higher & \pm & 20 & dead \\
\hline 13 & ly & $\mathrm{C}$ & $2 b$ & rich & intermixed & nd & nd & 4 & dead \\
\hline 14 & ly & $\mathrm{C}$ & $2 \mathrm{c}$ & rich & intermixed & nd & nd & 94 & alive \\
\hline 15 & ly & $\mathrm{C}$ & $2 b$ & rich & nodular & nd & nd & 6 & dead \\
\hline 16 & $2 y$ & $\mathrm{C}$ & $2 \mathrm{~b}$ & rich & nodular & nd & nd & 14 & dead \\
\hline 17 & $2 y$ & $\mathrm{C}$ & $2 a$ & poor & undifferent & higher & \pm & 76 & alive \\
\hline 18 & $3 y$ & $\mathrm{C}$ & $3 a$ & poor & undifferent & higher & \pm & 23 & dead \\
\hline 19 & $5 y$ & $\mathrm{C}$ & $3 a$ & poor & undifferent & higher & \pm & 22 & dead \\
\hline 20 & $5 y$ & $\mathrm{C}$ & $3 a$ & poor & undifferent & higher & \pm & 14 & dead \\
\hline 21 & $8 y$ & $\mathrm{C}$ & $2 \mathrm{a}$ & poor & undifferent & higher & - & 35 & dead \\
\hline 22 & $8 y$ & $\mathrm{C}$ & $2 a$ & poor & undifferent & higher & \pm & 41 & dead \\
\hline 23 & $9 y$ & $\mathrm{C}$ & $3 \mathrm{a}$ & poor & undifferent & lower & nd & 107 & alive \\
\hline 24 & $9 y$ & $\mathrm{C}$ & $2 b$ & rich & nodular & nd & nd & 71 & alive \\
\hline & $\begin{array}{l}\text { Group A } \\
\text { Group B } \\
\text { Group C }\end{array}$ & $\begin{array}{l}\text { screened } \\
\text { non-screer } \\
\text { non-scree }\end{array}$ & $\begin{array}{l}\text { ses } \\
\text { ed cases unde } \\
\text { ed cases over }\end{array}$ & $\begin{array}{l}\text { one year } \\
\text { ne year }\end{array}$ & $\begin{array}{l}\text { of age } \\
\text { age }\end{array}$ & $\begin{array}{l}\text { different } \\
\text { ferent; }\end{array}$ & $\begin{array}{l}\text { undiffere } \\
\text { ifferentiat }\end{array}$ & $\begin{array}{l}\text { ntiated histo } \\
\text { ing histology }\end{array}$ & $\log y$ \\
\hline & $\begin{array}{l}2 a ; \text { gan } \\
2 b ; \text { gan } \\
2 c ; \text { gan } \\
3 a ; \text { neu } \\
3 b ; \text { neu }\end{array}$ & $\begin{array}{l}\text { oneuroblas } \\
\text { ioneurobla } \\
\text { oneuroblas } \\
\text { blastoma, } \\
\text { blastoma, }\end{array}$ & $\begin{array}{l}\text { toma, well dif } \\
\text { toma, compos } \\
\text { oma, poorly } \\
\text { osette-fibrillar } \\
\text { ound cell type }\end{array}$ & $\begin{array}{l}\text { rentiated } \\
\text { te type } \\
\text { ifferentiat } \\
\text { type }\end{array}$ & $\begin{array}{l}\text { type } \\
\text { d type }\end{array}$ & determ & ned & & \\
\hline
\end{tabular}

stroma-rich type which had been found by MS (Fig. 4). In group C, the proportion of cases with a stroma-rich tumor increased (5/13), and the stroma-poor tumors were a higher-MKI tumor unlike that in the group of under one-year-old. All of the seven cases 


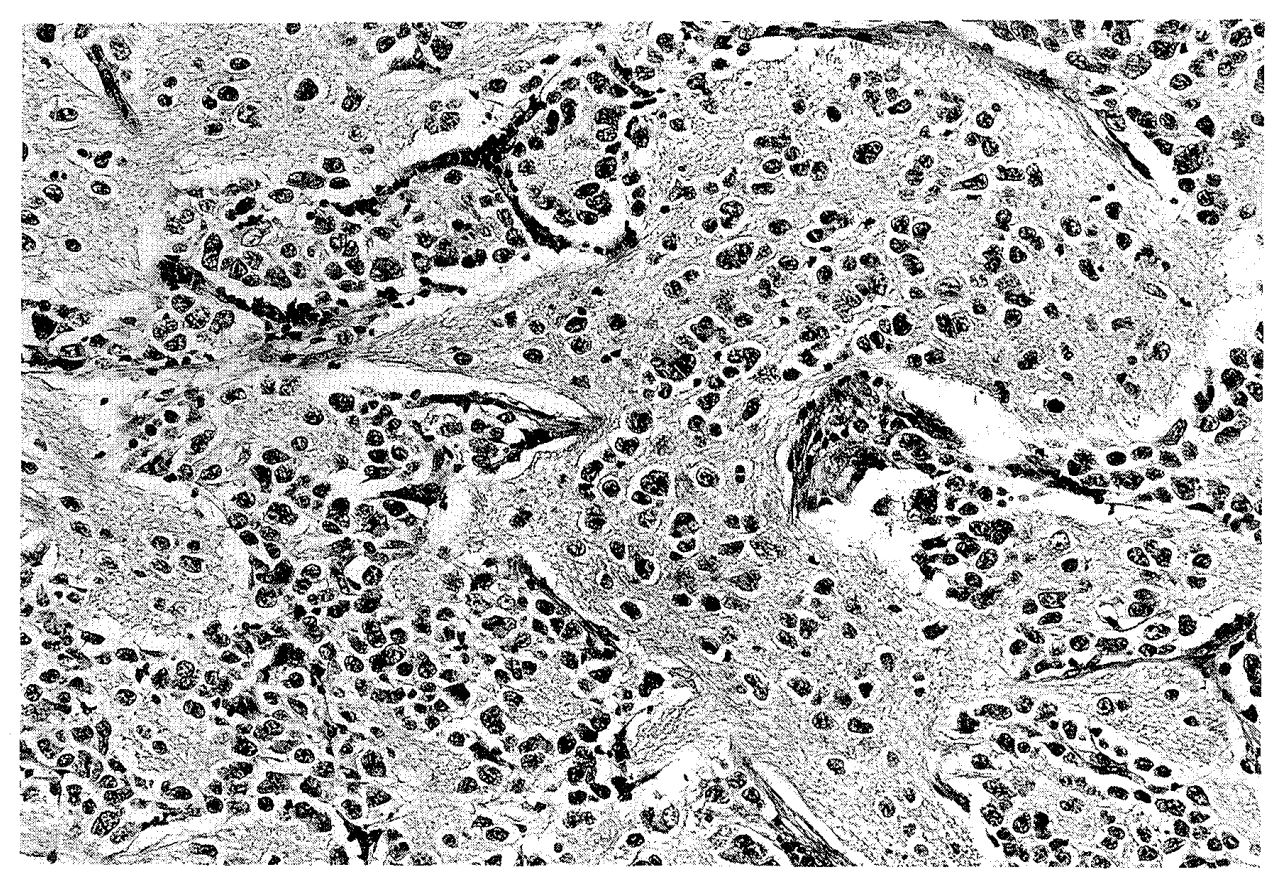

Fig. 4 Stroma-rich with neuroblastoma (patient 11) according to the classification of Shimada et al. [20]. Hematoxylin-eosin stain. $\times 50$.

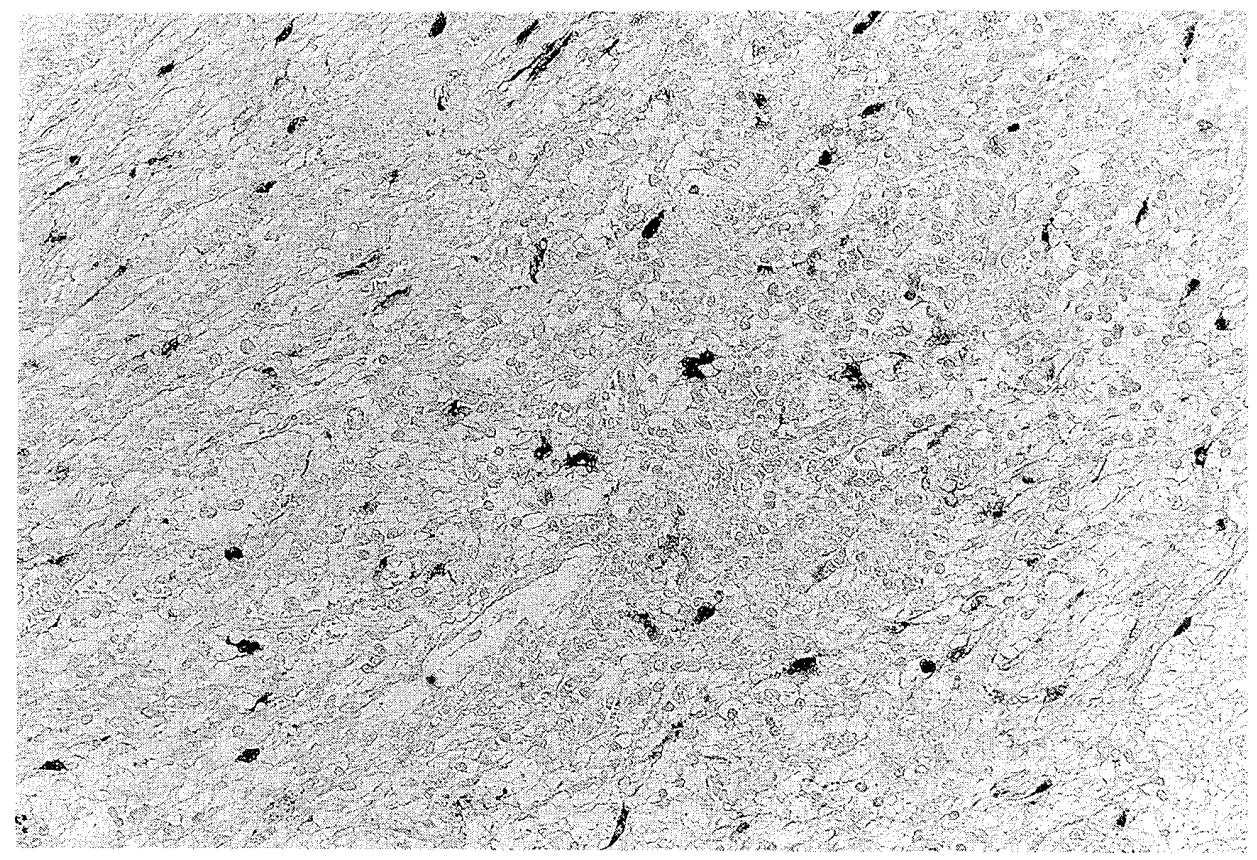

Fig. 5 S-100 protein positive stroma-poor neuroblastoma (patient 10$) . \quad \times 50$.

whose tumors with stroma-poor had been stained for S-100 protein under one year of age were positive (Fig. 5), whereas all cases in group C were negative for S-100 protein (chisquare $=14, P<0.0002$ ) and six of seven cases died (Fig. 6). 


\begin{tabular}{|c|c|c|}
\hline S- 100 protein & \multicolumn{2}{|c|}{ Age at diagnosis } \\
\hline staining & $<1$-year-old & $\geqq 1$-year-old \\
\hline Positive & & \\
\hline Negative & & \\
\hline . & & $\mathrm{de}$ \\
\hline
\end{tabular}

Fig. 6 Results of S-100 protein staining for the cases with stroma-poor neuroblasoma. Chi-square analysis showed that the correlation between the rate of positivity of S-100 protein staining and patients' age was significant (chi-square $=14, P=0.0002$ ).

\section{Discussion}

Since the opening of our University Hospital, 109 children's malignancies, which included 53 leukemias, 24 neuroblastomas, 11 malignant lymphomas, 7 Wilms' tumors, 6 yolk sac carcinomas, 2 rhabdomyosarcomas, 2 fibrosarcomas, 2 hepatoblastomas, an osteosarcoma, and a retinoblastoma, have been managed by the pediatric tumor outpatient clinic. According to the registration of childhood patients with maligant tumors in Japan during the 15-year period from 1969 to 1983, neuroblastoma accounted for $1893(10.3 \%)$ of 18325 patients with the proportion the greatest among childhood cases of solid tumors excluding brain tumors $[5-7]$. However, the mortality rate of neuroblastoma is still high, even though the cure of childhood malignant tumors such as acute lymphocytic leukemia, has been significantly improved by the development of combined-chemotherapy and supportive therapy $[22,23]$. MS for neuroblastoma was started with the view to improve the prognosis by early detection and early treatment.

There have been many studies regarding factors affecting the prognosis of neuroblastoma, and some factors, such as age at diagnosis, clinical stages [24-33], serum NSE [34] and ferritin levels [35], are reliable. With regard to biological characteristics, amplification of the $\mathrm{N}$-myc gene $[17,36-50]$ and the existence of chromosomal aberration $[18,51-54]$ are currently attracting attention. However, most under one-year-old patients with neuroblastoma do not have such risk factors. Six of seven screened cases found by Kitakyushu City System were treated in our department. All screened cases, two of whom were in the advanced clinical stages, had none of these risk factors. Regarding the N-myc gene, which is considered to be very closely correlated with the prognosis, its rate of amplification in the group of cases aged under one year was obviously different from that of patients aged over one year (chi-square $=46.74, P=0.0001$ ), although the amplification of the $\mathrm{N}$-myc gene was distinctly correlated with the prognosis in both groups $[17,36-40,42,43,45,47]$ (Table 3). It is suggested that the oncological characteristics of neuroblastoma in cases aged under one year are different from those in patients aged over one year. 
Table 3. Age and rate of $\mathrm{N}$-myc gene amplification

\begin{tabular}{|c|c|c|c|c|c|c|c|}
\hline \multirow[b]{2}{*}{ Reporter } & \multicolumn{3}{|c|}{ Under 1-year-old } & \multicolumn{3}{|c|}{ Over 1-year-old } & \multirow[b]{2}{*}{$\begin{array}{l}\text { Ref. } \\
\text { No. }\end{array}$} \\
\hline & $\begin{array}{l}\text { Number of N-myc } \\
\text { amplification }(+)\end{array}$ & $\begin{array}{l}\text { Number of } \mathrm{N}-\mathrm{myc} \\
\text { amplification }(-)\end{array}$ & $\begin{array}{l}\text { Rate of } \\
\text { amplification }\end{array}$ & $\begin{array}{l}\text { Number of N-myc } \\
\text { amplification }(+)\end{array}$ & $\begin{array}{l}\text { Number of } N \text {-myc } \\
\text { amplification }(-)\end{array}$ & $\begin{array}{l}\text { Rate of } \\
\text { amplification }\end{array}$ & \\
\hline Sugio K et al & 0 & 12 & $0 / 12$ & 9 & 12 & $9 / 21$ & 36 \\
\hline Tsuda $\mathrm{H}$ et al & 1 & 2 & $1 / 3$ & 13 & 13 & $13 / 16$ & 37 \\
\hline Cohn SL et al & 5 & 6 & $5 / 11$ & 5 & 13 & $5 / 18$ & 38 \\
\hline Taylor SR et al & 1 & 7 & $1 / 8$ & 1 & 9 & $1 / 10$ & 39 \\
\hline Hayashi $\mathrm{Y}$ et al & 0 & 37 & $0 / 37$ & 3 & 8 & $3 / 11$ & 40 \\
\hline Salvc I et al & 0 & 14 & $0 / 14$ & 1 & 9 & $1 / 10$ & 42 \\
\hline Hashimoto $\mathrm{H}$ et & al & 4 & $0 / 4$ & 9 & 5 & $9 / 14$ & 43 \\
\hline Brodeur GM et a & al & 15 & $2 / 17$ & 14 & 31 & $14 / 45$ & 45 \\
\hline Tsuda $\mathrm{T}$ et al & 2 & 13 & $2 / 15$ & 17 & 17 & $17 / 34$ & 17 \\
\hline Nakagawara et at & 3 & 38 & $3 / 41$ & 23 & 39 & $23 / 62$ & 47 \\
\hline Total & 14 & 148 & $14 / 162$ & 95 & 146 & $95 / 241$ & \\
\hline
\end{tabular}

Chi-square analysis showed that the correlation between N-myc amplification and patients' age in total was significant $\left(x^{2}=45.74, \mathrm{df}=1, P=0.0001\right)$

In histopathological studies, it was noted that ganglioneuroblastoma was observed in 9 of 13 cases over one-year-old while it was observed in only 2 of 11 cases under one-yearold. Since ganglioneuroblastoma might almost correspond to a stroma-rich tumor in the classification of Shimada et al., who reported that the stroma-rich tumor was a gradual progressive type along a maturational sequence according to the age of the patient [20], it is considered that ganglioneuroblastoma is a more matured type of the neuroblastic tumor than neuroblastoma. It is generally believed that the maturation of neuroblastoma is correlated with a good prognosis. Has MS discovered neuroblastoma in the process of maturation? In 24 cases, two cases with ganglioneuroblastoma under one-year-old were detected by MS. According to the national registration of maligant neoplasm of children in Japan from 1969 to 1984, the proportion of ganglioneuroblastoma in 6- to 12-month-old infants was only $6 \%$ before the beginning of MS [5-7], whereas it reached $28 \%$ in the cases detected by MS [4]. This finding is a first as far as we know. Neuroblastoma with an increased incidence of S-100 protein positive cells, which were considered a marker of Schwann cells, also showed a good prognosis [21, 55].

Furthermore, it is well known that some neuroblastomas regress spontaneously [5667], which is considered to be strongly related to age, because the age of most of the previously reported cases was under one year. On the other hand, there has been no reports on the relationship between spontaneous regression and the size of a neuroblastoma. 
Table 4. Clinical data of 12 unfortunate cases (whose tumors occurred later, although no abnomality was observed in mass screening) in Fukuoka Prefecture, other than Kitakyushu City, Kumamoto Prefecture and Miyazaki Prefecture

\begin{tabular}{|c|c|c|c|c|c|c|}
\hline \multirow[b]{2}{*}{ No } & \multirow[b]{2}{*}{ Sex } & \multirow[b]{2}{*}{ Screening date } & \multirow{2}{*}{$\begin{array}{l}\text { Age at } \\
\text { diagnosis }\end{array}$} & \multicolumn{2}{|c|}{$\mathrm{VMA} / \mathrm{HVA}(\mu \mathrm{g} / \mathrm{mgcre})$} & \multirow[b]{2}{*}{ Stage } \\
\hline & & & & on mass screening & on diagnosis & \\
\hline 1 & $\mathrm{~F}$ & Jul, 1985 & ly $10 \mathrm{~m}$ & $7.6 / 24.5$ & $54.5 / 91.1$ & III \\
\hline 2 & M & Dec, 1985 & $4 y \quad 2 m$ & $3.7 / 5.1$ & $43.2 / 489.4$ & $?$ \\
\hline 3 & M & Jul, 1986 & $3 y \quad 9 m$ & $7.6 / 17.3$ & $97.9 / 258.7$ & IV \\
\hline 4 & M & Aug, 1986 & $2 \mathrm{y} \quad 2 \mathrm{~m}$ & $8.5 / 38.6$ & ? & III \\
\hline 5 & $\mathrm{~F}$ & Aug, 1986 & ly $10 \mathrm{~m}$ & $4.6 / 11.3$ & $7.9 / 78.5$ & IV \\
\hline 6 & M & Sep, 1986 & $2 \mathrm{y} \quad 0 \mathrm{~m}$ & $5.7 / 15.3$ & $78.9 / 128.5$ & IV \\
\hline 7 & M & Jul, 1987 & $1 \mathrm{y} 11 \mathrm{~m}$ & $4.5 / 6.9$ & $14.4 / 50.7$ & $?$ \\
\hline 8 & $\mathrm{~F}$ & Jul, 1987 & $1 \mathrm{y} 9 \mathrm{~m}$ & $6.6 / 17.4$ & $23.0 / 18.9$ & III \\
\hline 9 & $\mathrm{~F}$ & Aug, 1987 & $2 \mathrm{y} 3 \mathrm{~m}$ & $14.4 / 12.1$ & $?$ & ? \\
\hline 10 & $\mathrm{~F}$ & Oct, 1987 & $1 \mathrm{y} 3 \mathrm{~m}$ & $7.3 / 10.2$ & $13.0 / 16.8$ & IV \\
\hline 11 & M & Nov, 1987 & $2 y \quad 5 m$ & $11.7 / 15.6$ & $228.9 / 508.6$ & IV \\
\hline 12 & $\mathrm{~F}$ & Dec, 1988 & $10 \mathrm{~m}$ & $8.0 / 13.0$ & $420.8 / 229.2$ & IV $-\mathrm{S}$ \\
\hline
\end{tabular}

Small tumors in the abdomen, which were not palpable, were $42 \%$ of 293 screened cases [4]. It has been known that at least in the colon small tumors of less than $1 \mathrm{~cm}$ in diameter become malignant on rare occasions, because multistep-progression has not occurred in them [68]. Knudson et al., who proposed the two-hit theory, concluded that a neuroblastoma that sustains one-hit alone shows spontaneous regression $[69,70]$. The incidences of neuroblastoma are increasing in various other countries [71-73], and the possibility that changes in environmental carcinogens are involved in this phenomenon cannot be denied $[71,74]$. However, the annual incidences of neuroblastoma in infancy before the beginning of MS, that is, 17.5/1,000,000 live births, increases to 71.3/1,000,000 live births after the screening began. The increase in incidences of infants with neuroblastoma after the introduction of MS, suggests that MS can pick out the cases that have one-hit alone according to Knudson's hypothesis. Matsumura et al. reported the spontaneous regressed case [75]. The level of urinary HVA of this case was still high and the tumor was detected by the ultrasound scan at 18 months of age, when he received the resection. In our case, who showed spontaneously regression, urinary levels of both VMA and HVA were normalized at 10 months of age by which time the right suprarenal tumor had disappeared. Most neuroblastomas in infancy might be expected to spontaneously regress or mature, and are likely to be a one-hit tumor.

Neuroblastoma having an amplified $\mathrm{N}$-myc gene, which would cause an unfavorble progonsis, might be more difficult to detect by MS, since there is a reverse-correlation among the amplification of the N-myc gene and the metabolism of catecholamines [76] . 
In Fukuoka Prefecture, other than Kitakyushu City, Kumamoto Prefecture and Miyazaki Prefecture, where urinary levels of catecholamines are determined by the same method as in Kitakyushu City, 12 cases (who were negative by MS, and occurred later) were overlooked during the period of 45 months after the inauguration of MS. Eight of the 12 cases had advanced clinical stages (Table 4). Ishimoto et al. concluded that MS at six months of age is too early to detect a neuroblastoma with unfavorable prognosis [9]. They proposed that MS at the age of one year and six months would be more effective. Our study confirmed that most of the screened cases were neuroblastoma with a favorable prognosis. But the fact that MS has markedly improved the survival rate of infants with neuroblastoma should be evaluated. We believe that the abolition of the current MS would result in a worsening of the outcome of neuroblastoma in infants. We therefore propose to introduce rescreening into a health survey program for infants aged one year and six months in Kitakyushu City. If the second MS for neuroblastoma at the age of one year and six months is enforced, it is estimated from the national registration that over 20 patients with neuroblastoma per 1,000,000 live births would be detected. The cost for one sample is about 1,000 yen. For the management of this program, 10,000,000 yen is needed in Kitakyushu City every year. The medical cost of treating an older child identified as having clinical symptoms with clinically advanced stages is a minimum of 10,000,000 yen. It must never be forgotten that there is no radical treatment for advanced neuroblastoma in older children and evaluation of the cost-benefit of MS is important.

\section{Acknowledgments}

I wish to thank Dr. J Okamura, Section of Pediatrics, National Kyushu Cancer Center, for supplying the histopathological specimens and Dr. K Higashi, Department of Biochemistry, School of Medicine, University of Occupational and Environmental Health, Japan, and Dr. Y Kaneko, Department of Laboratory Medicine, Saitama Cancer Center, for the analysis of the $\mathrm{N}$-myc gene and the chromosome. The author is also grateful to Dr. M Nakano, Second Department of Pathology, School of Medicine, University of Occupational and Environmental Health, Japan, for pathological comments and Prof. M Yamagishi, Department of Pediatrics, School of Medicine, University of Occupational and Environmental Health, Japan, for reviewing the manuscript and making helpful suggestions.

\section{References}

1. Sawada T, Todo S, Fujita K et al (1982): Mass screening of neuroblastoma in infancy. Am J Dis Child 136: 710-712

2. Sawada T, Hirayama M, Nakata T et al (1984): Mass screening for neuroblastoma in infants in Japan. Lancet 2: $271-273$

3. Kitakyushu medical association (1985): Mass Screening Program for Neuroblastoma. (Kitakyushu medical association, ed). Kitakyushu pp $1-5$ (in Japanesc) 
4. Sawada T, Nagahara N, Hata A et al (1990): Annual report of neuroblastoma cases detected by mass screening in Japan. Jpn J Ped Oncol 27: 15-18 (in Japanese)

5. Committee of Japan children's cancer registry (1977): All Japan Children's Cancer Registry. (Children's Cancer association of Japan, ed). Tokyo pp 74-83 (in Japanese)

6. Committee of Japan children's cancer registry (1980): All Japan Children's Cancer Registry. Vol 2. (Children's Cancer association of Japan, ed). Tokyo pp 44-56 (in Japanese)

7. Committee of Japan children's cancer registry (1987): All Japan Children's Cancer Registry. Vol 3. (Children's Cancer association of Japan, ed). Tokyo pp 28-63 (in Japanese)

8. Committee of Japan children's cancer registry (1990): Japan children's cancer registry in 1989. Pediatric Oncology 28: 733-755 (in Japanese)

9. Ishimoto K, Kiyokawa N, Fujita H et al (1990): Problems of mass screening for neuroblastoma: Analysis of false negative cases. J Pediatr Surg 25: 398-401

10. Nishi M, Miyake H, Takeda T et al (1989): Cases of neuroblastoma missed by the mass screening programs. Pediatr Res 26: 603-607

11. Oda T, Nishihira H, Toyoda Y et al (1992): Analysis of patients with advanced neuroblastoma who were not found by the mass screening program. J Jpn Pediatr Soc 96: 1040-1045 (in Japanese)

12. Evans AE, D’Angio GJ \& Radolph J (1971): A proposed staging for childern with neuroblastoma. Cancer 27: 374-378

13. Kitakyushu public health bureau (1991): Unpublished data.

14. Umehashi $\mathrm{T}$ (1989): Current status of mass screening by high-performance liquid chromatography. In: Mass Screening for Neuroblastoma (Boshi-Aiikukai, ed). Imperial Gift Foundation Boshi-Aiikukai, Tokyo pp. 94-101 (in Japanese)

15. Fujisawa T, Yamaguchi Y, Sasaki K et al (1985): Serum neuron-specific enolase as a marker of lung cancer. Jpn J Cancer Chemother 12: 139-143 (in Japanese)

16. Goto Y Niitsu Y, Nakamura Y et al (1986): Fundamental study and clinical use of ferritin kit "Daiichi". J Med Pharmace Sci 16: 113-120 (in Japanese)

17. Tsuda T, Obara M, Hirano $\mathrm{H}$ et al (1987): Analysis of $\mathrm{N}$-myc amplification in relationship to disease stage and histologic types in human neuroblastomas. Cancer 60: 820-826

18. Kaneko Y, Kanda N, Okabe I et al (1987): Different karyotypic patterns in early and advanced stage neuroblastomas. Cancer Res 47: 311-318

19. Shimizu K (1985): Tumors of the neuroblastoma group. In: Histological Classificantion and Atlas of Tumors in Infancy and Childhood 1. 2nd ed (Committee on histological classification of childhood tumors, Japanese Pathological Society, ed). Kanahara-Shuppan, Tokyo pp. 46-49 (in Japanese)

20. Shimada H, Chatten J, Newton WA et al (1884): Histopathologic prognostic factors in neuroblastic tumors: Definition of subtypes of ganglioneuroblastoma and an age-linked classification of neuroblastoma. J Natl Cancer Inst 73: 405-416

21. Shimada H, Aoyama C, Chiba T et al (1985): Prognostic subtypes for undifferentiated neuroblastoma: Immunohistochemical study with anti S-100 protein antibody. Hum Pathol 16: 471-476

22. Miller RW (1989): Frequency and environmental epidemiology of childhood cancer. In: Pediatric Oncology (Pizzo PA, Poplack DG, ed). Lippincott Co, Philadelphia pp 3-18

23. Neglia JP, Meadows AT, Robinson LL et al (1991): Second neoplasms after acute lymphoblastic leukemia in childhood. $\quad \mathrm{N}$ Engl J Med 325: 1330-1336

24. Wilson LMK \& Draper GJ (1974): Neuroblastoma, its natural history and prognosis; a study of 487 cases. Br J Med 3: 301-307

25. Coldman AJ, Frayer GJH, Elwood JM et al (1980): Influence of age at diagnosis, tumor site and sex on prognosis. Cancer 46: 1896-1901

26. Jaffe N (1976): Neuroblastoma; review of the literature and examination of factors contributing to its enigmatic character. Cancer Treat Rep 3: 61-82

27. Breslow N \& McCann B (1971): Statistical estimated of progonsis of children with neuroblastoma. 
Cancer Res 31: 2098-2103

28. Carlsen NLT, Christensen LJ, Schroeder H et al (1986): Prognostic factors in neuroblastoma treated in Denmark from 1943 to 1980 . A statistical estimate of prognosis based on 253 cases. Cancer 58: $2726-2735$

29. Carlsen NLT (1988): Why age has independent prognostic significance in neuroblastomas. Evidence for intrauterine development, and implications for the treatment of the disease. Anticancer Res 8: $255-262$

30. Evans AE, D’Angio GJ, Propert K et al (1987): Prognostic factors in neuroblastoma. Cancer 59: $1853-1859$

31. Hassenbusch S, Katzer H \& White JJ (1976): Prognostic factors in neuroblastic tumors. J Pediatr Surg 3: 287-297

32. Varakarakis MJ, Bhananlaph $\mathrm{T} \&$ Albert DJ (1973): Current status of prognostic criteria in neuroblastoma. J Urol 109: 94-97

33. Jerab B, Bretsky SS, Vogel R et al (1984): Age and prognosis in neuroblastoma. Am J Pediatr Hematol Oncol 6: 233-243

34. Zelter PM, Marangos PJ, Evans AE et al (1986): Serum neuron-specific enolase in children with neuroblastoma. Cancer 57: 1230-1234

35. Hann HW, Evans AE, Siegel SE et al (1985): Prognostic importance of serum ferritin in patients with stage III and IV neuroblastoma. Cancer Res 45: 2843-2848

36. Sugio K, Nakagawara A \& Sasazuki T (1991): Association of expression between N-myc gene and major histocompatibility complex class I gene in surgically resected human neuroblastoma. Cancer 67: $1384-1388$

37. Tsuda H, Shimosato Y, Upton MP et al (1988): Retrospective study on amplification of N-myc and C-myc genes in pediatric solid tumors and its association with prognosis and tumor differentiation. Lab Invest 59: 321-327

38. Cohn SL, Rademarker AW, Salwen HR et al (1990): Analysis of DNA ploidy and proliferative activity in relation to histology and N-myc amplification in neuroblastoma. Am J Pathol 136: 1043-1052

39. Taylor SR \& Locker J (1990): A comparative analysis of nuclear DNA content and N-myc gene amplification in neuroblastoma. Cancer 65: 1360-1366

40. Hayashi $\mathrm{Y}, \mathrm{Kanda} \mathrm{N}$, Inaba $\mathrm{T}$ et al (1989): Cytogenetic findings and prognosis in neuroblastoma with emphasis on marker chromosome 1. Cancer 63:126-132

41. Grady-Leopardi EF, Schwab M, Ablin AR et al (1986): Detection of N-myc oncogene expression in human neuroblastoma by in situ hybridization and blot analysis: Relationship to clinical outcome. Cancer Res 46: 3196-3199

42. Salvc I, Ellenbogen R, Jung WH et al (1990): myc Gene amplification and expression in human primary neuroblastoma. Cancer Res 50: 1459-1463

43. Hashimoto H, Daimaru Y, Enjoji M et al (1989): N-myc gene product expression in neuroblastoma. J Glin Oncol 42: $52-55$

44. Nakagawara A, Ikeda K, Tsuda T et al (1987): Amplification of N-myc oncogene in stage II and IVs neuroblastomas may be a prognostic indicator. J Pediatr Surg 22: 415-418

45. Brodeuer GM, Seeger RC, Schwab M et al (1984): Amplification of N-myc in untreated human neuroblastomas correlates with advanced disease stage. Science 224: 1121-1124

46. Combaret V, Wang Q, Favrot MC et al (1989): Clinical value of N-myc oncogene amplification in 52 patients with neuroblastoma included in recent therapeutic protocols. Eur J Cancer Clin Oncol 25: $1607-1612$

47. Nakagawara A, Ikeda K, Yokoyama T et al (1988): Surgical aspects of N-myc oncogene amplification of neuroblastoma. Surgery 104: 34-40

48. Nakagawara A, Sasazuki T, Akiyama $\mathrm{H}$ et al (1990): N-myc oncogene and stage IV-S neuroblastoma. Cancer 65: 1960-1967 
49. Nakagawara A, Ikeda K, Tsuda $\mathrm{T}$ et al (1987): N-myc oncogene amplification and prognostic factors of neuroblastoma in children. J Pediatr Surg 22: 895-898

50. Seeger RC, Brodeur GM, Sather H et al (1985): Association of multiple copies of the N-myc oncogene with rapid progression of neuroblastomas. N Engl J Med 313: 1111-1116

51. Suzuki T, Yokota J, Mugishima H et al (1989): Frequent loss of heterozygosity on chromosome 14q in neuroblastoma. Cancer Res 49: 1095-1098

52. Franke F, Rudolph B, Christiansen H et al (1986): Tumor karyotype may be important in the prognosis of human neuroblastoma. J Cancer Res Clin Oncol 111: 266-272

53. Hayashi Y, Handa R, Yamamoto K et al (1987): Chromosome findings and prognosis in neuroblastoma. Cancer Genet Cytogenet 29: 175-177

54. Hayashi Y, Inaba T, Handa R et al (1988): Chromosome findings and prognosis in 15 patients with neuroblastoma found by VMA mass screening. J Pediatr 112: 567-571

55. Nakagawara A, Nakagawara M, Scavarda NJ et al (1993): Association between high levels of expression of TRK gene and favorable outcome in human neuroblastoma. $\quad \mathrm{N}$ Engl J Med 328: 847-854

56. Everson TC \& Cole WH (1966): A study and abstracts of reports in the world medical literature and personal communication concerning spontaneous regression of malignant disease. In: Spontaneous Regression of Cancer. WB Saunders, Philadelphia pp 11-87

57. Jhonson CCJ \& Spitz MR (1985): Neuroblastoma; case-control study analysis of birth characteristics. J Natl Cancer Inst 74: 789-792

58. Miller RW (1977): Ethnic differences in cancer occurrence genetic and environmental influences with particular reference to neuroblastoma. In: Genetics of Human Cancer. (Mulvilhill JJ, Miller RW, Fraumeni JF, ed). Raven Press, New York pp 1-14

59. Hellstrom I, Hellstrom KE \& Bill AH (1978): Studies on cellular immunity to human neuroblastoma cells. Int J Cancer 6: 172-188

60. Varakis J, ZuRhein JM, Padgett BL et al (1978): Induction of peripheral neuroblastomas in Syrian hamsters after injection as neonates with JC virus, a human polyoma virus. Cancer Res 38 : $1718-1722$

61. Wertheim P \& Voute PA (1976): Neuroblastoma, Wilms' tumor, and cytomegalovirus. JNCI 57: $701-703$

62. Frantz CN (1980): Origin of neuroblastoma IV-S. N Engl J Med 30:820-821

63. Evans AE, Chatten J, D'Angio GJ et al (1980): A review of 171 V-S neuroblastoma patients at the children's hospital of Philadelphia. Cancer 45:833-839

64. Evans AE, Gerson J \& Schnaufer L (1976): Spontaneous regression of neuroblastoma. Natl Cancer Monogr 44: 49-54

65. Cole WH (1974): Spontaneous regression of cancer: The metabolic triumph of the host. Ann NY Acad Sci 230: 111-146

66. Knudson AG \& Meadows AT (1976): Developmental genetics of neuroblastoma. J Natl Cancer Inst 57: $675-682$

67. Schwartz AD, Dadash-Zenden M, Lee H et al (1974): Spontaneous regression of disseminated neuroblastoma. J Pediatr 85: 760-763

68. Vogelstein B, Fearon ER, Hamilton SR et al (1988): Genetic alterations during colorectal-tumor development. N Engl J Med 319: 525-532

69. Knudson AG \& Meadows AT (1980): Regression of neuroblastoma IV-S; a genetic hypothesis. N Engl J Med 302: 1254-1256

70. Moolgaokar SH \& Knudson AG (1981): Maturation and cancer: A model for human carcinogenesis. J Natl Cancer Inst 66: 1037-1052

71. Carlsen NLT (1986): Epidemiological investigations on neuroblastomas in Denmark. Br J Cancer 54: $977-988$

72. Ericsson JLE, Karnstrom L \& Mattoson B (1978): Childhood cancer in Sweden, 1958-1974. Acta 
Paediatr Scand 67: 425-432

73. Davis S, Rogers MA \& Pendergrass TW (1987): The incidence and epidemiologic characteristics of neuroblastoma in the United States. Am J Epidemiol 126: 1063-1074

74. Schottenfeld D (1981): The epidemiology of cancer: An overview. Cancer 47: 1095-1108

75. Matsumura M, Tsunoda A, Nishi $\mathrm{T}$ et al (1991): Spontaneous regression of neuroblastoma detected by mass screening. Lancet 338: 447-448

76. Nakagawara A, Ikeda K, Higashi K et al (1990): Inverse correlation between N-myc amplification and catecholamine metabolism in children with advanced neuroblastoma. Surgery 107: 43-49

マススクリーニングによって発見された神経芽腫症例と非マススクリーニング例

の臨床的特性および予後の相違：

北九州市における神経芽腫マススクリーニングの有用性

\section{有吉 宣明}

産業医科大学小星科学教室

要旨：当科腫瘍外来の 109 例の悪性腫瘍患者のうち, 固形腫瘍では神経芽腫が最も多く, 開院 以来 24 例が管理されている。神経芽腫はスクリーニング可能で，我々が市医師会と協力 して開始した北九州方式によるマススクリーニング (MS)により，当市では6 年間に 64,885 名の 6 力月坚の中から，7例の神経芽腫が発見されている。当科で管理中の 6 例 においては，血清神経特異性エノラーゼ，フェリチン高值や N-myc 遺伝子の増幅あるい は細胞遺伝学的異常など，従来いわれてきた子後に関する危険因子は，認められなかった。 病理組織学的には, 1 歳以上の例では, 神経節芽細胞腫が 13 例中 9 例を占めていたのに 対し，1歳未満では 11 例中 2 例にすぎず，そのいずれもがMS 例であった. Shimada ら の分類で，MS 例の 1 例は乳児期にはまれで，成熟型と考えられている間質増生型腫瘍で あり，自然退縮例も存在したのに対し，1藏以上の非 MS 例は, 13 例中 9 例が死亡して いる.MS 例の中には, 成熟または自然退縮過程にあって, 良好な予後が期待される神経 芽腫が含まれている可能性がある．MS 例の治療成績が著しく良好であるにもかかわらず， 1 歳以上で発症する神経芽腫の予後は，依然として不良であり，年長奣の神経芽腫を救済 するためには，1歳 6 カ月健診時に再スクリーニングを取り入れるべきと考えられた。

J UOEH（産業医科大学雑誌）15 (4): 251-266 (1993) 